\title{
Promicromonospora flava sp. nov., isolated from sediment of the Baltic Sea
}

\author{
Yi Jiang, ${ }^{1,2}$ Jutta Wiese, ${ }^{1}$ Yan-Ru Cao, ${ }^{2}$ Li-Hua Xu, ${ }^{2}$ Johannes F. Imhoff ${ }^{1}$ \\ and Cheng-Lin Jiang ${ }^{2}$ \\ ${ }^{1}$ Leibniz-Institut für Meereswissenschaften, IFM-GEOMAR, Düsternbrooker Weg 20, D-24105 Kiel, \\ Germany \\ ${ }^{2}$ Yunnan Institute of Microbiology, Yunnan University, Kunming 650091, PR China
}

Correspondence

Cheng-Lin Jiang

lihxu@ynu.edu.cn

Johannes F. Imhoff

jimhoff@ifm-geomar.de
The genus Promicromonospora was proposed by Krasil'nikov et al. (1961). Members of the genus are characterized by the production of substrate mycelia that fragment into bacillary or coccoid elements, no branched fatty acids, MK- $9\left(\mathrm{H}_{4}\right)$ as the major menaquinone and a DNA G + C content of 70-75 mol\%. The genus comprises the recognized species Promicromonospora aerolata (Busse et al. 2003), P. citrea (Krasil'nikov et al. 1961), P. sukumoe (Takahashi et al. 1987), P. vindobonensis (Busse et al. 2003) and P. kroppenstedtii (Alonso-Vega et al. 2008). As part of a research programme on actinomycete diversity in the Baltic Sea, Germany, taxonomic and comparative studies using a polyphasic approach were carried out with strain CC $0387^{\mathrm{T}}$ and related species and genera. A novel species of the genus Promicromonospora is proposed.

Strain CC $0387^{\mathrm{T}}$ was isolated from a sediment sample collected from the Baltic Sea, Germany, on fucose-proline medium made with Baltic Sea water [containing $\left(1^{-1}\right): 5 \mathrm{~g}$ fucose, $1 \mathrm{~g}$ proline, $1 \mathrm{~g}\left(\mathrm{NH}_{4}\right)_{2} \mathrm{SO}_{4}, 1 \mathrm{~g} \mathrm{NaCl}, 2 \mathrm{~g} \mathrm{CaCl}_{2}$, $1 \mathrm{~g} \mathrm{~K}_{2} \mathrm{HPO}_{4}, 1 \mathrm{~g} \mathrm{MgSO}_{4} .7 \mathrm{H}_{2} \mathrm{O}, 20 \mathrm{~g}$ agar; $\mathrm{pH}$ 7.2] with $20 \mathrm{mg}$ nalidixic acid and $100 \mathrm{mg}$ nystatin as inhibitors of

The GenBank/EMBL/DDBJ accession number for the 16S rRNA gene sequence of strain CC $0387^{\top}$ is AM992980.

A table showing the chemotaxonomic characteristics of strain $\mathrm{CC} 0387^{\top}$ and other species of the genus Promicromonospora is available as supplementary material with the online version of this paper. bacteria and fungi, after incubation at $28{ }^{\circ} \mathrm{C}$ for 21 days. The strain was maintained on medium YIM 83 (Difco marine broth $37 \mathrm{~g}$, peptone $2 \mathrm{~g}$ ) at $28{ }^{\circ} \mathrm{C}$ for 5 days.

Mycelial morphology was observed by using two models of light microscopy (Olympus microscope $\mathrm{BH}-2$ and LYSUPER HP CCD IMAGING) after incubation at $28{ }^{\circ} \mathrm{C}$ for 3 and 7 days, respectively. Cultural characteristics were determined after growth on six media, ISP (International Streptomyces project) 2, ISP 4, ISP 5 (Shirling \& Gottlieb, 1966) Czapek's agar and nutrient agar for 14 days at $28{ }^{\circ} \mathrm{C}$. The results were recorded following incubation at $28{ }^{\circ} \mathrm{C}$ for 14 days. Colours and hues were determined according to Kelly (1964). Strain CC $0387^{\mathrm{T}}$ was examined for a range of phenotypic properties using standard procedures (Williams et al., 1983). Enzyme activities were determined by using API ZYM system test kits (bioMérieux).

Biomass for the molecular systematic and most of the chemotaxonomic studies was obtained after incubation of cultures in yeast extract-malt extract broth (ISP 2; Shirling \& Gottlieb, 1966) supplemented with the vitamin mixture of HV medium (Hayakawa \& Nonomura, 1987) and $20 \mathrm{~g}$ $\mathrm{NaCl} 1^{-1}$ at $28{ }^{\circ} \mathrm{C}$ for 5 days with shaking. Cell walls were purified and the amino acids of peptidoglycan were analysed by TLC (Lechevalier \& Lechevalier, 1980; Jiang et al., 2001). Analysis of whole-cell sugar composition followed procedures described by Becker et al. (1965) and 
Lechevalier \& Lechevalier (1980). Phospholipid analysis was carried out as described by Lechevalier et al. (1981). Menaquinones were determined by using the procedure of Collins et al. (1977). Biomass for quantitative fatty acid analysis was prepared by scraping colonies from $3 \%(\mathrm{w} / \mathrm{v})$ trypticase soy (BBL) plates (1.5\%, w/v, Bacto agar; Difco) after incubation at $28{ }^{\circ} \mathrm{C}$ for 5 days. The fatty acids were extracted, methylated and analysed using the standard Microbial Identification system (Sasser, 1990). The chromosomal DNA of strain CC $0387^{\mathrm{T}}$ was extracted as described by Marmur (1961). The DNA G +C content was determined by using HPLC (Tamaoka \& Komagata, 1984) with an Agilent 1000 LC system (IRIS Technologies). The sequence of the 16S rRNA gene (1612 nucleotides) of strain CC $0387^{\mathrm{T}}$ was determined. Phylogenetic analysis based on 16S rRNA gene sequences was carried out using the procedures previously described (Jiang et al., 2008).
Strain CC $0387^{\mathrm{T}}$ was aerobic and Gram-positive. No aerial mycelium was produced on any of the six media tested (ISP 2, ISP 3, ISP 4, ISP 5, Czapek's agar and nutrient agar). Substrate mycelia fragmented into non-motile, coccoid, Y-shaped, V-shaped or curved bacillary elements. No sessile spores or other spore-like elements were observed. Cultures developed weakly on Czapek's agar (Dong \& Cai, 2001) but developed well on yeast extractmalt extract agar (ISP 2), oatmeal agar (ISP 3), inorganic salts-starch agar (ISP 4), glycerol-asparagine agar (ISP 5) and nutrient agar (Dong \& Cai, 2001). The substrate mycelium on these media was yellowish white to pale orange-yellow.

Physiological and biochemical characteristics, utilization of carbon and nitrogen sources and acid production by strain CC $0387^{\mathrm{T}}$ are described in Table 1 and the species description. Enzyme activities are shown in Table 1. The cell wall of strain CC $0387^{\mathrm{T}}$ contained lysine and alanine.

Table 1. Characteristics that differentiate strain $\mathrm{CC} 0387^{\top}$ and other species of the genus Promicromonospora

Strains: 1, Promicromonospora flava sp. nov. CC $0387^{\mathrm{T}} ; 2$, P. vindobonensis $\mathrm{V} 45^{\mathrm{T}} ; 3$, P. aerolata $\mathrm{V} 54 \mathrm{~A}^{\mathrm{T}} ; 4$, P. sukumoe $\mathrm{NBRC}^{14650^{\mathrm{T}}}$; 5 , P. citrea NBRC $12397^{\mathrm{T}}$; 6, P. kroppenstedtii RS16 ${ }^{\mathrm{T}}$ (Alonso-Vega et al., 2008). Data are from this study except for column $6 .+$, Positive; - , negative; w, weak reaction; ND, no data available.

\begin{tabular}{|c|c|c|c|c|c|c|}
\hline Characteristic & 1 & 2 & 3 & 4 & 5 & 6 \\
\hline Menaquinones & $\begin{array}{c}\text { MK-9 }\left(\mathrm{H}_{4}\right), \\
\text { MK-8 }\left(\mathrm{H}_{4}\right), \\
\text { MK-9 }\left(\mathrm{H}_{2}\right), \text { MK-9 }\end{array}$ & $\begin{array}{r}\operatorname{MK}-9\left(\mathrm{H}_{4}\right), \\
\operatorname{MK}-9\left(\mathrm{H}_{2}\right), \\
\operatorname{MK}-9\left(\mathrm{H}_{6}\right)\end{array}$ & $\begin{array}{l}\text { MK-9 }\left(\mathrm{H}_{4}\right) \\
\text { MK-9 }\left(\mathrm{H}_{2}\right)\end{array}$ & $\begin{array}{c}\text { MK-9 }\left(\mathrm{H}_{4}\right), \\
\left.\text { MK-9, MK-9(H }{ }_{2}\right), \\
\text { MK-9 }\left(\mathrm{H}_{6}\right)\end{array}$ & MK-9 & $\begin{array}{c}\text { MK-9 }\left(\mathrm{H}_{4}\right), \text { MK- } \\
9\left(\mathrm{H}_{6}\right), \mathrm{MK}-8\left(\mathrm{H}_{4}\right), \\
\mathrm{MK}-9\left(\mathrm{H}_{2}\right)\end{array}$ \\
\hline Cell-wall composition & Lys: Ala $(\mathrm{A} 3 \alpha)$ & $\begin{array}{l}\text { Glu : Gly : Ala : Lys } \\
\text { (A3 } \alpha)\end{array}$ & $\begin{array}{l}\text { Glu : Gly : Ala : Lys } \\
\text { (A3 } \alpha)\end{array}$ & Lys $(\mathrm{A} 3 \alpha)$ & $\begin{array}{l}\text { Lys : Ala } \\
\text { (A3 } \alpha)\end{array}$ & $\begin{array}{c}\text { Ala : Glu : Lys } \\
\text { (A4 } \alpha)\end{array}$ \\
\hline Cell-wall sugars ${ }^{\star}$ & Rib, Gal, Glu, Rha & Rha, Gal, Glu & Rha, Gal, Glu & ND & Gal & Gal, Rha \\
\hline Oxidase & - & + & + & - & - & + \\
\hline Nitrate reduction & + & + & + & - & + & + \\
\hline Gelatin hydrolysis & - & - & $\mathrm{W}$ & + & + & + \\
\hline \multicolumn{7}{|l|}{ API ZYM assays } \\
\hline Acid phosphatase & - & + & - & + & + & + \\
\hline$\alpha$-Chymotrypsin & - & - & $\mathrm{W}$ & - & - & - \\
\hline Trypsin & - & $\mathrm{W}$ & $\mathrm{W}$ & + & + & $\mathrm{W}$ \\
\hline \multicolumn{7}{|l|}{ Assimilation of: } \\
\hline D-Arabinose & - & + & - & $\mathrm{w}$ & - & - \\
\hline D-Fructose & - & + & + & + & + & - \\
\hline Galactose & - & - & $\mathrm{w}$ & + & + & - \\
\hline D-Glucose & + & - & - & + & + & + \\
\hline Lactose & + & + & + & $\mathrm{W}$ & + & + \\
\hline Maltose & - & + & + & + & + & - \\
\hline Mannitol & - & - & + & + & + & + \\
\hline D-Mannose & - & + & + & + & + & - \\
\hline Raffinose & - & + & - & - & + & - \\
\hline Rhamnose & - & $\mathrm{W}$ & - & - & + & + \\
\hline Ribose & + & + & + & + & $\mathrm{W}$ & + \\
\hline Sorbitol & - & - & - & $\mathrm{W}$ & - & + \\
\hline L-Sorbose & - & - & - & $\mathrm{w}$ & - & + \\
\hline Starch & + & + & + & + & + & - \\
\hline Sucrose & + & - & - & + & + & + \\
\hline Trehalose & + & - & + & + & + & + \\
\hline
\end{tabular}

${ }^{*}$ Gal, Galactose; Glu, glucose; Rha, rhamnose; Rib, ribose. 
Whole-cell hydrolysates contained ribose, galactose, glucose and rhamnose. The polar lipid profile consisted of diphosphatidylglycerol, phosphatidylglycerol, an unknown phospholipid and an unknown glycolipid. The predominant menaquinone was $\mathrm{MK}-9\left(\mathrm{H}_{4}\right)(86 \%)$ with minor amounts of $\mathrm{MK}-8\left(\mathrm{H}_{4}\right)(6.65 \%)$, MK-9 $\left(\mathrm{H}_{0}\right)(2.64 \%)$ and MK-9 $\left(\mathrm{H}_{2}\right)(4.80 \%)$. The genomic DNA G $+\mathrm{C}$ content of strain CC $0387^{\mathrm{T}}$ was $71.87 \mathrm{~mol} \%$ (HPLC).

Phylogenetic analysis was conducted using 16S rRNA gene sequences of Promicromonospora species and representatives of other genera in the family Promicromonosporaceae. The database search (BLAST) and neighbour-joining tree showed that strain CC $0387^{\mathrm{T}}$ belonged to the genus Promicromonospora (Krasil'nikov et al. 1961) and displayed more than $3 \%$ sequence divergence from all recognized species of the genus Promicromonospora: P. sukumoe NBRC $14650^{\mathrm{T}}$ (96.86\% similarity), P. aerolata NBRC $16526^{\mathrm{T}}$ (96.54\%), $P$. citrea DSM $43110^{\mathrm{T}}(96.56 \%), \quad P$. vindobonensis $\mathrm{V} 45^{\mathrm{T}}$ (96.55\%) and P. kroppenstedtii $\mathrm{RS}^{\mathrm{T}}{ }^{\mathrm{T}}$ (96.56\%) (Fig. 1). The similarities between strain CC $0387^{\mathrm{T}}$ and each of the five recognized species were lower than the similarities among the five species. The maximum-likelihood tree supported this result (data not shown).

Strain CC $0387^{\mathrm{T}}$ was isolated on a medium prepared with natural marine water and grew well in media containing
2-5\% (w/v) $\mathrm{NaCl}$. Strain CC $0387^{\mathrm{T}}$ did not produce acid from any of the 25 carbon sources tested, which distinguishes it from all other species of Promicromonospora. Fatty acid components of the five recognized species of the genus Promicromonospora and strain CC $0387^{\mathrm{T}}$ were different, especially in the proportion of several major fatty acids: iso$\mathrm{C}_{15: 0}$, anteiso- $\mathrm{C}_{15: 0}$, iso- $\mathrm{C}_{16: 0}$ and anteiso- $\mathrm{C}_{17: 0}$. The proportion of anteiso- $\mathrm{C}_{15: 0}$ in strain $\mathrm{CC} 0387^{\mathrm{T}}$ was $57.20 \%$, whereas it was below $51.1 \%$ in other Promicromonospora species, and the proportion of iso$\mathrm{C}_{15: 0}$ in strain CC $0387^{\mathrm{T}}$ was $16.26 \%$ whereas it was more than $30.8 \%$ in the other Promicromonospora species (Supplementary Table S1, available in IJSEM Online). To date, 18 genera of actinobacteria, Aeromicrobium, Aureobacterium, Corynebacterium, Dermacoccus, Dietzia, Gordonia, Kokuria, 'Marinomyces', Micromonospora, Mycobacterium, Nocardia, Rhodococcus, Salinispora, Salinibacterium, Streptomyces, Tsukamurella, Verrucosispora and Williamsia have been isolated and characterized from marine samples (Jiang et al., 2007). No member of the genus Promicromonospora from marine samples has yet been described. However, on the basis of morphological, chemotaxonomic, phenotypic and genetic characteristics, strain CC $0387^{\mathrm{T}}$ represents a novel species of the genus Promicromonospora, for which the name Promicromonospora flava sp. nov. is proposed.

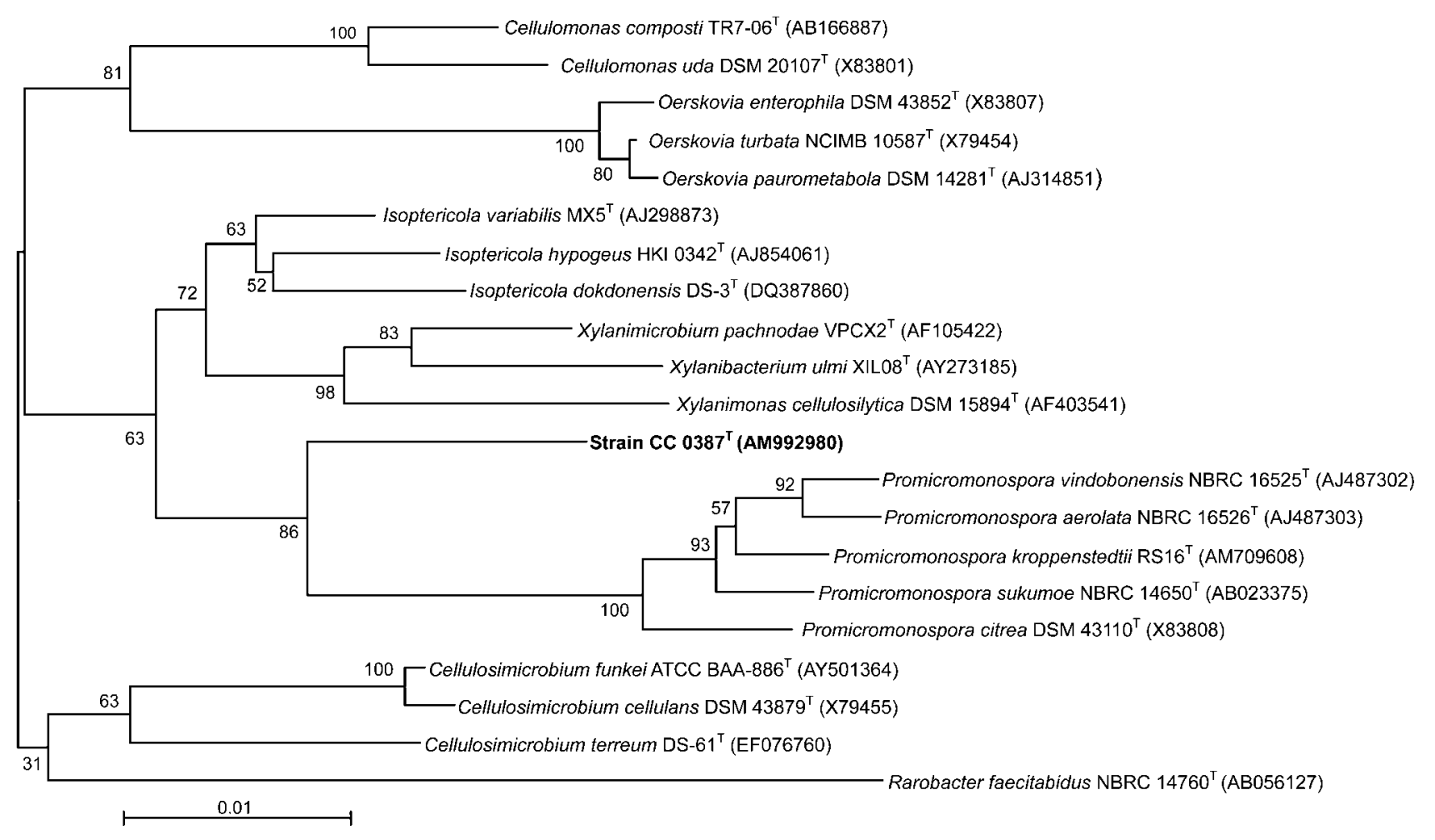

Fig. 1. Neighbour-joining phylogenetic tree derived from 16S rRNA gene sequences showing the relationship of strain CC $0387^{\top}$ and species of related genera of the family Promicromonosporaceae. Numbers at branch nodes are bootstrap percentages (1000 replications). Bar, $1 \%$ sequence divergence. 


\section{Description of Promicromonospora flava sp. nov.}

Promicromonospora flava (fla'va. L. fem. adj. flava yellow, being a yellowish organism).

Aerobic, Gram-positive. No aerial mycelium is produced on all six media tested. Substrate mycelia fragment into nonmotile, coccoid, Y-shaped, V-shaped or curved bacillary elements. No sessile spores or other spore-like elements are observed. Grows weakly on Czapek's agar but develops well on ISP 2, ISP 3, ISP 4, ISP 5 and nutrient agar. Substrate mycelium on different media is yellowish white to pale orange-yellow. Grows well in media containing 2-5\% (w/v) $\mathrm{NaCl}$. Nitrate reduction is positive. Gelatin liquefaction, milk coagulation and peptonization, starch hydrolysis, growth on cellulose and production of $\mathrm{H}_{2} \mathrm{~S}$ and melanin are negative. D-Glucose, inositol, lactose, ribose, starch, sucrose, trehalose, xanthine and xylitol are utilized as sole carbon sources with no production of acid. D-Arabinose, dextrin, aesculin, erythritol, D-fructose, galactose, glycine, histidine, lysine, maltose, mannitol, D-mannose, melibiose, raffinose, rhamnose, sodium DL-malate, sorbose, sorbitol, succinic acid and xylose are not utilized. Cell wall contains alanine and lysine. Whole-cell hydrolysates contain galactose, glucose, rhamnose and ribose. Phospholipids consist of diphosphatidylglycerol, phosphatidylglycerol, an unknown phospholipid and an unknown glycolipid. The predominant menaquinone is MK-9 $\left(\mathrm{H}_{4}\right)$. Major fatty acid components are anteiso- $\mathrm{C}_{15: 0}$ and iso- $\mathrm{C}_{15: 0}$. The genomic DNA G+C content of the type strain is $71.87 \mathrm{~mol} \%$.

The type strain CC $0387^{\mathrm{T}}\left(=\right.$ CCTCC AA208024 ${ }^{\mathrm{T}}=\mathrm{DSM}$ $21481^{\mathrm{T}}$ ) was isolated from a sediment sample collected from the Baltic Sea, Germany.

\section{Acknowledgements}

This research was supported by the National Basic Research Program of China (no. 2004CB719601), the National Natural Science Foundation of China (no. 30560001), International Cooperative Key Project of Ministry of Science and Technology (2006DFA33550), the Yunnan Provincial International Cooperative Program (no. 2005GH21), the Yunnan Provincial Natural Science Foundation (no. 2004 C0002Q) and the Center of Marine Natural Products, which is financed by the Ministry of Science, Economic Affairs and Transport of the State of Schleswig-Holstein (Germany). We thank Dr Zhang Yu-qin, Miss Cai Xiang-Feng and Mr Chen Yun for their technical assistance.

\section{References}

Alonso-Vega, P., Santamaría, R. I., Martínez-Molina, E. \& Trujillo, M. E. (2008). Promicromonospora kroppenstedtii sp. nov., isolated from sandy soil. Int J Syst Evol Microbiol 58, 1476-1481.
Becker, B., Lechevalier, M. P. \& Lechevalier, H. A. (1965). Chemical composition of cell-wall preparations from strains of various formgenera of aerobic actinomycetes. Appl Microbiol 13, 236-243.

Busse, H. J., Zlamala, C., Buczolits, S., Lubitz, W., Kämpfer, P. \& Takeuchi, M. (2003). Promicromonospora vindobonensis sp. nov. and Promicromonospora aerolata sp. nov., isolated from the air in the medieval 'Virgilkapelle' in Vienna. Int J Syst Evol Microbiol 53, 1503 1507.

Collins, M. D., Pirouz, T., Goodfellow, M. \& Minnikin, D. E. (1977). Distribution of menaquinones in actinomycetes and corynebacteria. J Gen Microbiol 100, 221-230.

Dong, X. Z. \& Cai, M. Y. (editors) (2001). Determination of biochemical properties. In Manual for the Systematic Identification of General Bacteria, pp. 370-398. Beijing: Science Press (in Chinese).

Hayakawa, M. \& Nonomura, H. (1987). Humic acid-vitamin agar, a new medium for selective isolation of soil actinomycetes. $J$ Ferment Technol 65, 501-509.

Jiang, L., Li, M., Li, W., Cui, X., Xu, L. \& Jiang, C. (2001). Study on the application of quantitative analysis of cell-wall amino acids in actinomycetes. Acta Microbiol Sin 41, 270-277.

Jiang, Y., Wiese, J., Xu, L. H., Imhoff, J. F. \& Jiang, C. L. (2007). Marine actinobacteria, an important source of novel secondary metabolites with bioactivities. Chin J Antibiot 32, 705-722.

Jiang, Y., Wiese, J., Tang, S.-K., Xu, L.-H., Imhoff, J. F. \& Jiang, C.-L. (2008). Actinomycetospora chiangmaiensis gen. nov., sp. nov., a new member of the family Pseudonocardiaceae. Int J Syst Evol Microbiol 58, 408-413.

Kelly, K. L. (1964). Inter-Society Color Council - National Bureau of Standards Color Name Charts Illustrated with Centroid Colors. Washington, DC: US Government Printing Office.

Krasil'nikov, N. A., Kalakoutskii, L. V. \& Kirillova, N. F. (1961). A new genus of Actinomycetales, Promicromonospora gen. nov. Ser Biol 1, 107-112.

Lechevalier, M. P. \& Lechevalier, H. A. (1980). The chemotaxonomy of actinomycetes. In Actinomycete Taxonomy, Special publication no. 6, pp. 227-291. Edited by A. Dietz \& J. Thayer. Arlington, VA: Society for Industrial Microbiology.

Lechevalier, M. P., Stern, A. E. \& Lechevalier, H. A. (1981). Phospholipids in the taxonomy of actinomycetes. Zentralbl Bakteriol Mikrobiol Hyg 1 (Suppl 11), 111-116.

Marmur, J. (1961). A procedure for the isolation of deoxyribonucleic acid from microorganisms. J Mol Biol 3, 208-218.

Sasser, M. (1990). Identification of bacteria by gas chromatography of cellular fatty acids. USFCC Newsl 20, 16.

Shirling, E. B. \& Gottlieb, D. (1966). Methods for characterization of Streptomyces species. Int J Syst Bacteriol 16, 313-340.

Takahashi, Y., Tanaka, Y., Iwai, Y. \& Omura, S. (1987). Promicromonospora sukumoe sp. nov., a new species of the Actinomycetales. J Gen Appl Microbiol 33, 507-519.

Tamaoka, J. \& Komagata, K. (1984). Determination of DNA base composition by reversed-phase high-performance liquid chromatography. FEMS Microbiol Lett 25, 125-128.

Williams, S. T., Goodfellow, M., Alderson, G., Wellington, E. M. H., Sneath, P. H. A. \& Sackin, M. J. (1983). Numerical classification of Streptomyces and related genera. J Gen Microbiol 129, 1743-1813. 